\title{
EFFECTS OF STARVATION AND ZINC INTAKE ON VITAMIN A AND E LEVELS IN THE BLOOD PLASMA OF PIGLETS
}

\author{
M. DVOKÁK \\ Veterinary Research Institute, 62132 Brno
}

Received fanuary 10, 1983

\begin{abstract}
Dvořák, M.: Effects of Starvation and Zinc Intake on Vitamin $A$ and $E$ Levels in the Blood Plasma of Piglets. Acta vet. Brno, 52, 1983: 49-57.

Blood plasma vitamin $\mathrm{A}$ and $\mathrm{E}$ levels of piglets were followed in four experiments for changes produced by weaning in the 4th week after birth, 5-day starvation, short-term food deprivation and by intake of zinc sulphate. The increase found in circulating vitamin A levels after weaning may have been promoted by lard supplements to the feed. Its decrease by $41 \%$ and $34 \%$ in two experiments during the starvation culminated on the 2 nd to 5 th day and was almost rectified after two days of refeeding. If piglets received an average of $480 \mathrm{mg}$ zinc per animal during the 5-day starvation, the decrease in blood plasma vitamin A level did not occur during the first two days and then was relatively low. In individual animals no consistent relation was found between the changes in blood plasma vitamin A levels and the vitamin A hepatic content that suggested a satisfactory vitamin A status. In fed piglets blood plasma vitamin A concentration increased after the mean daily intake of $344 \mathrm{mg}$ zinc added to the feed, but not after the intake of $144 \mathrm{mg}$ zinc. The effects are explained by the disappearance of postabsorption retinol esters from the blood during starvation and by increased retinol release from the liver due to high zinc supplements. Six-hour food deprivation did not affect the circulating vitamin A level, 18-hour food deprivation did so to a relatively small extent. Blood plasma vitamin $\mathrm{E}$ concentration decreased by more than $50 \%$ during 13 days after weaning and then changed only little under the subsequent experimental conditions. The five-day starvation produced a decrease in vitamin $\mathrm{E}$ in the liver.
\end{abstract}

Retinol, tccspherol, blood, liver, zinc.

An assessment of the vitamin A status of pigs and other animals involves certain problems if it is not possible to determine the size of the vitamin stores by examination of the liver. The determination of vitamin A concentration in the blood plasma or serum is regarded as less useful (Pitt 1981), but it has been widely used in both human and veterinary medicine and seems helpful also in pigs.

Circulating in the blood are retinol esters of alimentary origin, which are stored in the liver, and retinol released from the liver in combination with a specific transport protein, retinol-binding protein (RBP). Its secretion is blocked when vitamin A in the liver is deficient (S mith and Goodman 1979). It is generally believed that between extreme situations of depletion and saturation, plasma retinol level is constant even at considerable variations in the hepatic stores. Inadequate intake of vitamin $\mathrm{A}$ is compensated for by an internal regulatory mechanism which maintains its plasma level from endcgenous reserves at a height presumably required for optimum provision to the tissues. This homeostatic mechanism, however, may be affected by factors other than the vitamin A status of the body (Underwood et al. 1979). A number of them have been identified (Pitt 1981). One of these factors may also be zinc (Smith et al. 1976; Solomons and Russell 1980).

In pigs, however, blood plasma vitamin A concentration is not constant during the rearing period. It decreased when pigs were changed to a feed of a lower vitamin A content even if their hepatic reserves were adequate. A considerable decrease was found in pigs at slaughter after food deprivation for one day (Dvoŕák and Herzig 1982). 
Vitamin A levels found in the blood plasma of healthy pigs and other animals have a remarkably wide range. Of diagnostic value is the minimum concentration that can be regarded as indicative of a still sufficient intake of vitamin A or carotens. In pigs it has not been determined with certainty. A previous study from our laboratory (Dvořák and Herzig 1982) suggested that in feeder pigs it is $0.6 \mu \mathrm{mol} .1^{-1}$ on non-restricted feeding and about $0.4 \mu \mathrm{mol} .1^{-1}$ after food deprivation for one day. The present study is an extension of the previous one; its objective was to investigate the changes after starvation for several days and increased zinc intake. At the same time consideration was given also to the changes in blood plasma vitamin $\mathrm{E}$ level which was previously found to be low in weaned piglets and feeder pigs (Dvoŕák 1974) and showed little change after pre-slaughter food withdrawal (Dvořák and Herzig 1982).

\section{Materials and Methods}

Blood plasma vitamin $\mathrm{A}$ and $\mathrm{E}$ concentrations were determined repeatedly in four experiments involving a total of 102 Large White $\times$ Landrace pigs weaned at 4 weeks of age under the following experimental conditions:

In Experiment 1, 13 piglets of Group S were fed a commercial prestarter (Čos 1) for the first 13 days and a commercial starter (ČOS 2 ) for the next 20 days after weaning except that no feed was offered and only water was available from the 26th to 31st day after weaning. Group F comprised 14 piglets fed a mixture consisting of 50 per cent CoS 1 and 50 per cent maize with supplements of 2 per cent lard and carbadox for the first 13 days and a mixture consisting of 50 per cent ČOS 2 and 50 per cent of a commercial grower (A 1) for the next 20 days after weaning. As compared with Group S, the feed content of crude protein $(\mathrm{N} \times 6.25)$ in Group $\mathrm{F}$ was reduced $32 \%$ and $13 \%$, that of vitamin A supplied by biofactor supplement by $50 \%$ and $37 \%$ (to 1.2 and $1.5 \mathrm{mg}$ retinol equivalent respectively) and the content of vitamin E declared was reduced $50 \%$ (to $15 \mathrm{mg}$ ) during both stages.

Piglets used in the next three experiments were fed ČOS 2. Experiment 2 involved three groups of 6 to 7 piglets 14 to 28 days after weaning. Group SZ piglets were deprived of food from the 21 st to 26th day; during this period they drank water supplemented with a solution of zinc salt $(0.4 \mathrm{~g}$ $\mathrm{ZnSO}_{4}$ per animal per day). Group S was also deprived of food for 5 days, but drank clean water. Group $\mathrm{F}$ was fed normally.

Experiment 3, which lasted one day, involved three groups of piglets 3 weeks after weaning. Group ZI (10 piglets) was given feed sprinkled with a zinc salt solution at the rate of $2.5 \mathrm{~g} \mathrm{ZnSO}_{4}$ per $\mathrm{kg}$ for one day. Group ZM (5 piglets) was given feed enriched with $1 \mathrm{~g} \mathrm{ZnSO}_{4}$ per $\mathrm{kg}$ and Group F (11 piglets) was fed normally.

Experiment 4, which lasted one day, involved two groups of 15 piglets 6 weeks after weaning. They were observed for the effects of food deprivation for 6 and 18 hours after feeding (from 8 to 14 hours or from 14 hours till 8 hours the next day).

All the groups were well balanced in regard to initial body mass, sex distribution as well as origin from individual litters (with the exception of Group ZM of Experiment 3) and were kept in the same environment. The feed mixtures were fed in the dry state ad libitum. Blood collections from the vena cava cranialis were made, unless indicated otherwise, at 8 a.m. without previous restriction of food intake. The intervals of blood collection are specified in Results. The piglets were observed for signs of clinical illness and for gains in body mass. If they were slaughtered, their liver mass was recorded. Vitamin A and E levels in the blood plasma and liver were determined fluorometrically according to Thomp son et al. $(1971,1973)$. The results are presented as arithmetic means \pm standard errors of the means. The significance of the differences of the means was assessed by Stundet's t-test.

\section{Results}

The two differently fed groups of Experiment 1 did not differ significantly from each other in the parameters under study up to day 26 after weaning (Fig. 1). Their body mass and gains were almost equal $(8.15 \pm 0.85$ and $8.14 \pm 0.76 \mathrm{~kg})$, but feed consumption per kg gain during the first 13 days was $16.1 \%$ higher in Group F. The blood plasma vitamin A level rose up to day 26 ; this increase was significant $(P<0.05)$ in Group F. The level of vitamin E fell abruptly $(P<0.01)$ during the first 13 days after weaning, being slightly lower in Group F. During the five-day starvation of Group S piglets, the body mass decreased $1.67 \pm 0.17 \mathrm{~kg}$, 
the blood plasma vitamin A level by $41 \%$ declining to $0.67 \pm 0.04 \mu \mathrm{mol} .1^{-1}$ $(P<0.01)$ and the already low vitamin $\mathrm{E}$ level remained practically unchanged. The subsequent feeding for two days produced an increase in body mass by $2.35 \pm 0.23 \mathrm{~kg}$ and an increase in vitamin A level by $34 \%$ to $0.92 \pm 0.02 \mu \mathrm{mol}^{-1} 1^{-1}$ $(P<0.01)$. The vitamin $\mathrm{E}$ level was unaffected (Fig. 1).
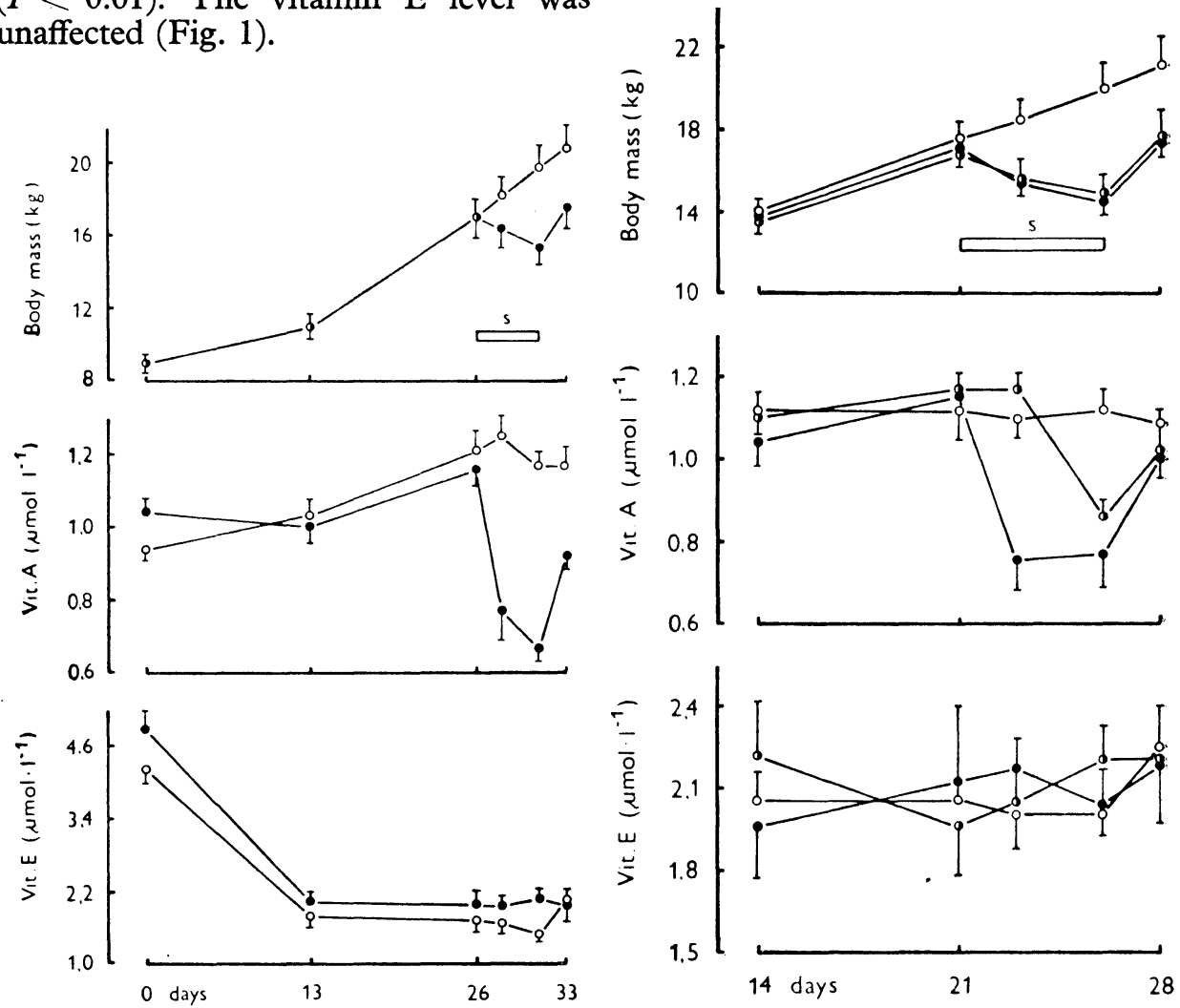

Fig. 1. Body mass and blood plasma vitamin $\mathrm{A}$ and $\mathrm{E}$ concentrations in two groups of piglets after weaning (day 0 ), one of which (closed circles) was fed more protein and vitamin A and $\mathrm{E}$ than the control group and was starved from day 28 to day 31 (s).

Fig. 2. Body mass and blood plasma vitamin $A$ and $E$ concentrations in three groups of piglets 14 to 28 days after weaning, one of which (closed circles) was starved from day 21 to day 26 (s), a second group was also starved but received zinc sulphate with drinking water (half-closed. circles) and a third group was fed normally.

After Experiment 1 was completed, 9 piglets of each group were slaughtered. Those of Group F were $1.35 \mathrm{~kg}$ heavier. The liver vitamin A concentration and total liver vitamin A content were $188.6 \pm 15.8 \mu \mathrm{mol} \mathrm{.} \mathrm{kg}{ }^{-1}$ and $24.3 \pm 3.2 \mathrm{mg}$, respectively, in Group $S$, and $170.9 \pm 10.5 \mu \mathrm{mol} . \mathrm{kg}^{-1}$ and $27.2 \pm 2.5 \mathrm{mg}$ in Group F. A non-significant difference was found also in vitamin $\mathrm{E}$ whose liver concentration and total liver content were $7.9 \pm 1.4 \mu \mathrm{mol} \mathrm{.} \mathrm{kg}{ }^{-1}$ and $1.5 \pm 0.3 \mathrm{mg}$, respectively, in Group $S$ and $9.1 \pm 1.4 \mu \mathrm{mol} . \mathrm{kg}^{-1}$ and $2.1 \pm 0.4 \mathrm{mg}$ in Group F. No consistent relation was found between the lower or higher liver vitamin A level and the lower or higher plasma vitamin A level after the 5-day starvation in individual piglets. 
In Experiment 2 the effect of 5-day starvation in Group $S$ was similar to that seen in Experiment 1, but the decrease in body mass was greater and the fall in plasma vitamin A concentration reached the lowest value, $0.76 \pm 0.09 \mu \mathrm{mol} .1^{-1}$ (a decrease by 34 per cent), as early as the second day (Fig. 2). In Group SZ, on the other hand, where each piglet received with water, on average, $2 \mathrm{~g}$ of $\mathrm{ZnSO}_{4}$, i.e. $480 \mathrm{mg}$ zinc, the blood plasma vitamin A concentration remained unchanged after two days of starvation and did not decrease until the fifth day when it declined to $0.85 \mu \mathrm{mol} .1^{-1}$. This decrease was also significant $(P<0.01)$, although the difference as against the pre-starvation level was only by $26 \%$. Two days after the starvation period the differences in vitamin A concentration between Groups $S$ and SZ were negligible again and the values recorded for the two groups were only non-significantly lower than that found in Group F. Blood plasma vitamin E levels of all three groups fluctuated, showing no distinct relation to food intake; an upward trend during starvation was seen in Group SZ (Fig. 2). There were no significant differences between either the groups or individual examinations.

After Experiment 2 was completed, 4 to 5 piglets from each group were slaughtered. The liver vitamin A concentration and total liver vitamin A content were $176.3 \pm 20.7 \mu \mathrm{mol} . \mathrm{kg}^{-1}$ and $20.5 \pm 3.1 \mathrm{mg}$, respectively, in Group SZ, $198.6 \pm$ $\pm 24,4 \mu \mathrm{mol} . \mathrm{kg}^{-1}$ and $22.1 \pm 2.0 \mathrm{mg}$ in Group $\mathrm{S}$, and $177.0 \pm 16.9 \mu \mathrm{mol} . \mathrm{kg}^{-1}$ and $24,5 \pm 2.6 \mathrm{mg}$ in Group $\mathrm{F}$. The differences were not significant. As to vitamin $\mathrm{E}$, on the other hand, its level was reduced by starvation, with the difference between Groups $\mathrm{S}$ and $\mathrm{F}$ being significant $(P<0.05)$. The liver vitamin $\mathrm{E}$ concentration and total liver vitamin $\mathrm{E}$ content were $5.4 \pm 0.9 \mu \mathrm{mol} \mathrm{.} \mathrm{kg}{ }^{-1}$ and $0.9 \pm 0.2 \mathrm{mg}$, respectively, in Group SZ, $3.9 \pm 0.6 \mu \mathrm{mol} . \mathrm{kg}^{-1}$ and $0.7 \pm 0.1 \mathrm{mg}$ in Group $\mathrm{S}$, and $7.4 \pm 0.8 \mu \mathrm{mol} . \mathrm{kg}^{-1}$ and $1.6 \pm 0.2 \mathrm{mg}$ in Group F. No similar differences between the groups were revealed by determination of vitamin $\mathrm{E}$ levels in the blood plasma. No consistent relation was found between the changes in blood plasma levels of vitamin A and its hepatic stores after starvation, even in individual animals.

In Experiment 3, the enrichment of the feed mixture with zinc did not affect food intake and the difference between the groups in body mass gain for the day under study was only negligible. In group ZI piglets averaging $13.5 \mathrm{~kg}$ in body mass each animal ingested, on average, $344 \mathrm{mg}$ zinc from the $\mathrm{ZnSO}_{4}$ supplement. The blood plasma vitamin A level rose significantly $(P<0.05)$ from $0.99 \pm 0.07$ to $\left.1.23 \pm 0.06 \mu \mathrm{mol} .1^{-1}\right)$. The increase occurred in all piglets regardless of the initial concentration. The vitamin E level of this group was almost unchanged $\left(1.75 \pm 0.16\right.$ vs. $\left.1.81 \pm 0.17 \mu \mathrm{mol} .1^{-1}\right)$. In Group $\mathrm{ZM}$ where the mean body mass was $15.1 \mathrm{~kg}$ and where each piglet ingested, on everage, $144 \mathrm{mg}$ zinc from the $\mathrm{ZnSO}_{4}$ supplement the vitamin A level was almost unchanged $(1.17 \pm 0.08$ vs. $1.13 \pm 0.06 \mu \mathrm{mol} .1^{-1}$ and the vitamin $\mathrm{E}$ level showed a mild decrease from $2.15 \pm 0.09$ to $1.92 \pm 0.12 \mu \mathrm{mol} .1^{-1}$. In Group $\mathrm{F}$ where piglets averaged $13.2 \mathrm{~kg}$ in body mass and received no zinc supplement the situation was similar to that seen in Group ZM; the concentrations of vitamin A were $1.12 \pm 0.04$ and $1.11 \pm$ $\pm 0.06 \mu \mathrm{mol} .1^{-1}$ and those of vitamin E were $2.19 \pm 0.12$ and $2.08 \pm 0.18 \mu \mathrm{mol} .1^{-1}$.

In Experiment 4, Group 1 piglets averaging $24.5 \mathrm{~kg}$ in body mass and fed hitherto ad libitum were deprived of food from the first blood collection at 8 hours, replaced on the ad libitum diet after the second blood collection at 14 hours and were continued on it to the third blood collection at 8 hours the next day. The 6-hour food deprivation and subsequent feeding did not affect the blood plasma vitamin $\mathrm{A}$ concentration $\left(1.12 \pm 0.05,1.11 \pm 0.06\right.$ and $\left.1.06 \pm 0.06 \mu \mathrm{mol}^{-1} \mathrm{l}^{-1}\right)$ 
and produced a non-significant decrease in the concentration of vitamin $\mathrm{E}(2.40 \pm$

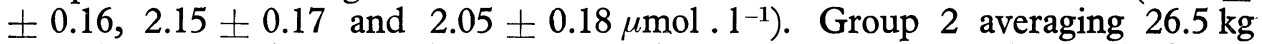
in body mass and examined at the same times as Group 1 was deprived of food from 14 hours to 8 hours the next day. After the 18-hour food deprivation, the blood plasma vitamin A concentration slightly decreased $(1.03 \pm 0.04,1.04 \pm 0.04$ and $0.97 \pm 0.04 \mu \mathrm{mol} \mathrm{.1}{ }^{-1}$ ) and so did the vitamin E concentration, but more during the first stage when the animals were still fed $(2.41 \pm 0.15,2.14 \pm 0.15$ and $2.02 \pm$ $\left.\pm 0.14 \mu \mathrm{mol} .1^{-1}\right)$.

\section{Discussion}

The present results confirmed our previous observations (Dvořák and Herzig 1982) that blood plasma vitamin $A$ and $E$ concentrations of piglets are not always constant and that the changes of the two vitamins are not interdependent. Tocopherolemia of piglets is most affected by weaning after which it fell more than $50 \%$ during the first 13 days with the vitamin $\mathrm{E}$ content declared in the prestarter ČOS 1 , playing no substantial role (Experiment 1). It changed neither consistently nor markedly during 5-day starvation; in piglets drinking at the same time water enriched with zinc it showed an upward trend (Experiment 2). On the other hand, tocopherolemia was unaffected by zinc supplementation of the feed (Experiment 3). Three blood collections during one day showed a non-significant decrease in tocopherolemia regardless of feeding or starvation (Experiment 4). A factor presumably involved in this case was the effect of stress-enhanced adrenocortical activity as was observed after administration of adrenocorticotrophic hormone (D vořák et al. 1980). The decrease in the liver content of vitamin $\mathrm{E}$ after 5 days of starvation shows that its stores are relatively small.

A decrease in plasma vitamin $E$ level occurs regularly in piglets after early weaning and was not prevented by tocopheryl acetate supplements to the feed. Tocopherolemia in weaned piglets is lower by as much as two thirds than in suckled piglets. This was explained by a vitamin $\mathrm{E}$ intake lower than that provided by ingestion of dams' milk and by the physiologically limited transport capacity resulting from decreased blood lipoprotein and fat metabolite levels under reduced alimentary fat intake (Dvořák 1974; Dvořák and Herzig 1982). Presumably, however, more than one factor are involved in this phenomenon, including the feed content of non-saturated and rancid fats which increase tocopherol requirements. It is noteworthy that a re-increase in plasma vitamin $\mathrm{E}$ level was observed as early as the 14th day, but also as late as the 75 th day after weaning (Dvoŕák and Herzig 1982). This was found in piglets whose body mass gain for 21 days was less than $4 \mathrm{~kg}$ or more than $6 \mathrm{~kg}$. In the present study the rise did not occur up to 33rd day after weaning at the total body mass gain of $8 \mathrm{~kg}$ for 21 days. This indicates a higher vitamin $\mathrm{E}$ consumption under intensive growth, but also under increased consumption of feed which can effect tocopherolemia adversely by its composition and quality in a secondary way.

The plasma vitamin E level of weaned piglets in the present study did not fall below $1 \mu \mathrm{mol} .1^{-1}$, but at such a low level it is no longer possible to differentiate with certainty between "physiological" and pathological values. Considering that diseases caused by deficiencies of vitamin $\mathrm{E}$ and possibly selenium occur aparticularly in weanlings and young feeder pigs (Trapp et al. 1970; Mahan nd Moxon 1980), this period should always be regarded as one during which piglets are at risk. 
Vitamin A concentration in the blood plasma of piglets is affected relatively little by weaning; it increases if piglets are fed a sufficient amount of prestarter or starter. A deciding role in this is played presumably by retinol content of the feed mixture, but the same effect was achieved also if retinol content was reduced (Experiment 1). It appears probable that fat supplements promote the absorption of liposoluble vitamin. The greatest decrease in vitamin A level, namely by 34 to $41 \%$, was recorded after starvation (Experiments 1 and 2) when the mean value fell to $0.67 \mu \mathrm{mol} .1^{-1}$ during 5 days. When piglets were subsequently fed normally for two days, their plasma vitamin A concentration recovered rapidly, but it failed to reach the prestarvation level. The effect of starvation was cancelled during the first two days and reduced afterwards by zinc intake with the drinking water (Experiment 2). The effect of zinc apparently depends on its quantity: when supplemented to feed at $144 \mathrm{mg}$ per animal $\left(9.6 \mathrm{mg} . \mathrm{kg}^{-1}\right)$, zinc showed no favourable effect, but the supplement of $344 \mathrm{mg}\left(25.5 \mathrm{mg} \cdot \mathrm{kg}^{-1}\right)$ produced a significant rise in plasma vitamin A concentration (Experiment 3) to the upper level occurring in piglets of similar age. It should be emphasized that the aforementioned changes in plasma vitamin A concentration were demonstrated under experimental conditions that do not exist in the field. Not even a dose of $0.5 \mathrm{~g}$ $\mathrm{ZnSO}_{4}(120 \mathrm{mg}$ zinc) per animal used in the treatment of parakeratosis may affect the metabolism of vitamin A. The usual interval from feeding to blood collection does not produce changes in plasma vitamin A level, since no decrease was found in its level after 6 hours and only a negligible one after 18 hours of food deprivation (Experiment 4). Only if pigs were not fed for at least 24 hours, as is the case before slaughter, the fall in vitamin A concentration was considerable (Dvořák and Herzig 1982). It is therefore not possible to use the same measure in evaluating blood plasma vitamin A level found at slaughter and that recorded in a herd after possible brief food deprivation. Moreover, the possibility cannot be excluded that some other factors additional to food deprivation are involved at slaughter, namely stress. Corticosteroids are known to cause a decrease in tissue concentrations of vitamin A (Sunethra Atukorala et al. 1981).

The results reported here suggest that the decrease of plasma vitamin A level after 24-hour starvation is not transient and may become even deeper on the 5th day. Presumably retinol esters absorbed from the alimentary tract after food ingestion disappear from the circulating blood and what remains there is only the retinol complex bound to $\mathrm{RBP}$, referred to as holo $\mathrm{RBP}$ and representing the physiologically active form of vitamin A (Glover 1980). Provided that its release from the liver is not disturbed, the state in the plasma during starvation represents the potential vitamin A concentration required by the tissues, which for weaned piglets would be 0.63 to $0.85 \mu \mathrm{mol} .1^{-1}$ as calculated by means of the standard errors of the means in our two experiments. This range suggests considerable individual variability even in animals of the same age under conditions of fairly large hepatic vitamin A concentration and high vitamin A requirements of intensively reared piglets. The concentration of $0.6 \mu \mathrm{mol} .1^{-1}$, which could be regarded as sufficient in non-starved feeder pigs, would suggest vitamin A deficiency in weaned piglets.

The decrease in blood plasma level of vitamin A after starvation could be explained also by its impaired release from the hepatic stores in consequence of low RBP production and secretion. This occurs particularly in deficiences of vitamin A, protein or zinc (Glover and Muhilal 1976; Smith at al. 1976; Smith and Goodman 1979; Solomons and Russell 1980). In pigs a decrease in 
circulating vitamin A level was found in zinc deficiency (Stevenson and Earle 1956), but was not confirmed (Palludan and Wegger 1975). In our experimental animals it is unlikely that the release of hepatic retinol was impaired by a zinc deficiency because their plasma vitamin A levels could not be increased until zinc was administered in pharmacological doses. This implies a probably direct involvement of zinc in the mechanisms controlling the circulating vitamin A concentration as is evident also from the observations on its intraperitoneal administration to rats (Ette et al. 1975).

The results of our assessment of blood plasma vitamin A levels in pigs deprived of food for 24 hours or longer imply a reduction and narrowing of the range of values regarded hitherto as "normal", namely $0.35-1.22, \mu \mathrm{mol} .1^{-1}$ (Slanina et al. 1975) and more than $0.88 \mu \mathrm{mol} .1^{-1}$ (Jagoš and Bouda 1981). According to our present knowledge this range is 0.39 to $0.85 \mu \mathrm{mol} .1^{-1}$ for animals whose hepatic stores are satisfactory. Examination of the blood from starving pigs may exclude misinterpretations of high concentrations resulting from a temporary major vitamin intake. Whether blood plasma vitamin A level during starvation can be used for diagnostic purposes must await further investigations.

\section{Účinek hladovění a podávání zinku na koncentraci vitamínu A a E v krvi selat}

Ve čtyřech pokusech byly u selat sledovány změny koncentrace vitaminu A a $\mathrm{E}$ v krevní plazmě působené odstavem ve 4 . týdnu stář́i, pětidenním hladověním, krátkodobým lačněním a přijmem síranu zinečnatého. Na zvýšení hladiny cirkulujícího vitamínu A se po odstavu může příznivě uplatnit přídavek sádla $\mathrm{v}$ krmivu. Její snížení při hladovění ve dvou pokusech o 41 a $31 \%$ kulminovalo $2 .-5$. den a po dvou dnech opětného krmení se téměř upravilo. V prvé dva dny nenastalo a poté bylo snížení redukováno, jestliže selata přijala během pětidenního hladovění průměrně $480 \mathrm{mg}$ zinku. $\mathrm{U}$ jedinců nebyl zjištěn pravidelný vztah změn v plazmě $\mathrm{k}$ obsahu vitaminu $\mathrm{A} v$ játrech, který svědčil pro dostatečné zajištění. U krmených selat se koncentrace vitaminu $\mathrm{A} v$ plazmě zvýšila po prủměrném denním př́ímu $344 \mathrm{mg}$ zinku přidaného do krmiva, ne však po př́ijmu $144 \mathrm{mg}$ zinku. Účinky jsou vysvětleny vymizením postabsorbčních esterù retinolu $z$ krve při hladovění a zvýšeným uvolňováním retinolu $\mathrm{z}$ jater při působení vysokých dávek zinku. Šestihodinové lačnění neovlivnilo hladinu cirkulujícího vitamínu A, osmnáctihodinové poměrně málo. Koncentrace vitamínu $\mathrm{E} v$ plazmě se během 13 dní po odstavu snižila více než o $50 \%$ a v průvběhu experimentálních podmínek se měnila jen málo a neprůkazně. Po pětidenním hladovění byl zjištěn úbytek vitaminu $\mathrm{E} v$ játrech.

Воздействие голодания и подачи цинка на концентрацию витаминов А и $\mathrm{E}$ в крови молодых поросят

В ходе четырех опытов на поросятах проводились наблюдения за изменениями концентрации витаминов $\mathrm{A}$ и $\mathrm{E}$ в кровяной плазме в результате отсадки на четвертой неделе возраста, пятидневного голодания, кратковременного содержания натощак и приема суьфата цинка. На повышение уровня циркулирующего витамина А после отсадки может оказать благоприятное влияние добавка сала в корм. Его понижение при голодовке в ходе 
двух опытов на 41 и $31 \%$ достигло кульминационной точки на второй и пятый день и после двухдневного повторного кормления почти достигло нормы. Первые двое суток понижение не наступило и в последствии оно было редуцировано благодаря подаче в среднем 480 мг цинка, назначаемого поросятам в течение пятидневного голодания. У отдельных поросят не было установ.Іено регулярного отношения изменений в плазме к содержанию витамина A в печени, свидетельствующего о достаточном обеспечении. Концентрация витамина А в плазме у кормленных поросят увеличилась после среднегс суточного приема 344 мг цинка, добавляемого в корм, однако не увеличилась после добавления 144 мг цинка. Воздействие объясняется исчезновением постабсорбционных эфиров ретинола из крови голодовке и повышением выделением ретинола из печени при воздействии высоких доз цинка. Шесгичасовое содержание натощак не оказало влияния на уровень циркулирующего витамина $\mathrm{A}$, восемнадцатичасовое - довольно незначительно. Концентрация витамина Е в плазме в течение 13 суток после отсадки понизилась более чем на $50 \%$ и в течение экспериментальных условий она изменялась лишь немного и незначимо. После пятисуточного голодания было установлено уменьшение витамина Е в печени.

\section{References}

DVOŘ́́K, M.: Levels of vitamin $\mathrm{E}$ in the blood plasma of suckling and weaned piglets. Acta vet. Brno, 43, 1974: $103-110$.

DVOŘ́́K, M. - HERZIG, I.: Koncentrace vitaminu A a E v krevní plazmě rostoucích prasat v závislosti na alimentárním př́imu a na věku. Vet. Med., Praha, 27, 1982: 665-679.

DVOŘÁ, M. - RASZYK, J. - ČANDERLE, J. - TOULOVÁ, M. - MATOUŠKOVÁ, O. : Effect of oestradiol, progesterone or testosterone on adrenocortical activity and on various metabolic parameters in ovariectomized gilts. Zbl. Vet. Med. A, 27, 1980: 765-774.

ETTE, S. I. - BASU, T. K. - DICKERSON, J. W. T.: Short-term effects of zinc sulphate on plasma and hepatic concentrations of vitamin $\mathrm{A}$ and $\mathrm{E}$ in normal weanling rats. Nurr. Metabolism. 23, 1979: 11 .

GLOVER, J.: Fluorescence assay of retinol-binding holoprotein. Meth. Enzym., 67, 1980: 282 to 287 .

GLOVER, J. - MUHILAL, H.: Nutritional factors affecting the biosynthesis of retinol-binding protein in the liver and its release into plasma. Int. J. Vitam. Nutr. Res., 46, 1976: 239-243.

JAGOŠ, P. - BOUDA, J.: Základní biochemické a hematologické hodnoty u domácích zviřat a nové způsoby vyjadřování výsledků laboratorních vyšetření. SVS, Oddělení veterinární osvěty, Pardubice, 1981: 29 p.

MAHAN, D. C. - MOXON, A. L.: Effect of dietary selenium and injectable vitamin E-selenium for weanling swine. Nutr. Rep. internat., 21, 1980: 829-836.

PALLUDAN, B. - WEGGER, I.: Zinkmangel og A vitamin status hos svin. Årsberetn. Inst. Sterilitetsforsk., 18, 1975: B 6-B. 8.

PITT, G. A. J.: The assessment of vitamin A status. Proc. Nutr. Soc., 40, 1981: 173-178.

SLANINA, L. et al.: Klinická propedeutika a diagnostika vnútorných chorob hospodárskych zvierat. Príroda, Bratislava, 1975, 583 p.

SMITH, J. C. - BROWN, E. D. - MCDANIEL, E. G. - CHAN, W.: Alterations in vitamin A metabolism during zinc deficiency and food and growth restriction. J. Nutr., 106, 1976: $569-574$.

SMITH, J. E. - GOODMAN, D. S.: Retinol-binding protein and the regulation of vitamin A transport. Fedn Proc., 38, 1979: 2504-2509.

SOLOMONS, N. W. - RUSSELL, R. M.: The interaction of vitamin A and zinc: implications for human nutrition. Am. J. clin. Nutr., 33, 1980: 2031-2040.

STEVENSON, J. W. - EARLE, I. P.: Studies on parakeratosis in swine. J. Anim. Sci., 15, 1956: $1036-1045$.

SUNETHRA ATUKORALA, T. M. - BASU, T. K. - DICKERSON, J. W. T.: Effect of corticosterone on the plasma and tissue concentrations of vitamin A in rats. Ann. Nutr. Metab., 25, 1981 : 234-238. 
THOMPSON, J. N. - ERDODY, P. - BRIEN, R. - MURRAY, T. K.: Fluorometric determination of vitamin $\mathrm{A}$ in human blood and liver. Biochem. Med., 5, 1971: 67-89.

THOMPSON, J. N. - ERDODY, P. - MAXWELL, W. B.: Simultaneous fluorometric determinations of vitamins $\mathrm{A}$ and $\mathrm{E}$ in human serum and plasma. Biochem. Med., 8, 1973: 403-414.

TRAPP, A. L. - KEAHEY, K. K. - WHITENACK, D. L. - WHITEHAIR, C. K.: Vitamin E-selenium deficiency in swine: Differential diagnosis and nature of field problem. J. Am. vet. med. Ass., 157, 1970: 289-300.

UNDERWOOD, B. A. - LOERCH, J. D. - LEWIS, K. C.: Effects of dietary vitamin A deficiency, retinoic acid and protein quantity and quality on serially obtained plasma and liver levels of vitamin A in rats. J. Nutr., 109, 1979: 796-806. 